\begin{tabular}{|c|c|}
\hline Title & $\begin{array}{l}\text { Reduction in blood pressure and vascular reactivities to pressor substances by chronic treatment } \\
\text { with piretanide in spontaneously hypertensive rats }\end{array}$ \\
\hline \multicolumn{2}{|r|}{ ( 1} \\
\hline Author & $\begin{array}{l}\text { 川島, 紘一郎(Kawashima, Koichiro) } \\
\text { 早川，晃正(Hayakawa, Terumasa) } \\
\text { 大畑，尚代(Ohata, Hisayo) } \\
\text { 藤本，和子(Fujimoto, Kazuko) } \\
\text { 鈴木，岳之(Suzuki, Takeshi) }\end{array}$ \\
\hline Publisher & 共立薬科大学 \\
\hline Publication year & 1989 \\
\hline Jtitle & $\begin{array}{l}\text { 共立薬科大学研究年報 (The annual report of the Kyoritsu College of } \\
\text { Pharmacy). No.34 (1989. ), p.88- } 88\end{array}$ \\
\hline \multicolumn{2}{|l|}{ JaLC DOI } \\
\hline \multicolumn{2}{|l|}{ Abstract } \\
\hline Notes & 抄録 \\
\hline Genre & Technical Report \\
\hline URL & $\begin{array}{l}\text { https://koara.lib.keio.ac.jp/xoonips/modules/xoonips/detail.php?koara_id=AN00062898-0000003 } \\
\text { 4-0088 }\end{array}$ \\
\hline
\end{tabular}

慶應義塾大学学術情報リポジトリ(KOARA)に掲載されているコンテンツの著作権は、それぞれの著作者、学会または出版社/発行者に帰属し、その権利は著作権法によって 保護されています。引用にあたっては、著作権法を遵守してご利用ください。

The copyrights of content available on the KeiO Associated Repository of Academic resources (KOARA) belong to the respective authors, academic societies, or publishers/issuers, and these rights are protected by the Japanese Copyright Act. When quoting the content, please follow the Japanese copyright act. 


\title{
Reduction in Blood Pressure and Vascular Reactivities to Pressor Substances by Chronic Treatment with Piretanide in Spontaneously Hypertensive Rats
}

\author{
Koichiro Kawashima, Terumasa Hayakawa, Hisayo Oohata, \\ Kazuko FujImoro and Takeshi SuzuKI \\ 川島紘一郎，早川晃正，大畑尚代，藤本和子，鈴木岳之
}

1. Effects of treatment with piretanide (10 and $30 \mathrm{mg} / \mathrm{kg}$ per day p.o.) for 9 weeks on blood pressure, urinary excretion of electrolytes, and vascular reactivities to pressor substances were investigated in 10-week-old spontaneously hypertensive (SHR) rats.

2. Piretanide $(30 \mathrm{mg} / \mathrm{kg})$ prevented development of hypertension and produced a significant reduction in blood pressure from the 2 nd week of the treatment. A slight decrease in blood pressure was observed in rats treated with the lower dose of piretanide.

3. Piretanide produced significant and dose-dependent diuresis throughout the experiment. Although significant natriuresis was observed in the 1 st and 4 th week of the treatment, natriuresis disappeared in the 8th week. Urinary excretion of potassium was decreased significantly by piretanide throughout the experiment.

4. Attenuation of pressor responses to phenylephrine and angiotensin II was observed after chronic administration of piretanide $(30 \mathrm{mg} / \mathrm{kg})$.

5 . These data demonstrate the contribution of attenuated vascular reactivities to pressor substances as well as a diuretic action to the antihypertensive effect of piretanide during its long-term administration in SHR rats.

* 本報告は Gen. Pharmacol., 20 (2) 213-217（1989）に発表. 